\title{
Modern Paradigm: Democratic Skills in a Higher Order Thinking Skills Frame
}

\author{
Guruh Prasetyo $^{1}$, Hermanu Joebagio ${ }^{2}$, Sri Yamtinah ${ }^{3}$ \\ ${ }^{1,2,3}$ Postgraduate te of Sebelas Maret University, Indonesia \\ Gprasetyo05@gmail.com
}

\begin{abstract}
The demand for expertise in technology and rapid service in the modern era has penetrated the field of education. According to Geogi Lozanov in Robinson (2005: 1) in reaching citizens who are sensitive to the development of science and technology and have the ability to interact internationally requires critical thinking skills and democratic attitudes. Critical thinking also requires skills to think about assumptions in asking questions about the concept of democracy that is being discussed before it becomes an option to be developed into a way of living together as a nation. Efforts to reach generations of citizens who have critical thinking skills and have democratic skills are one of the goals of national education, one of them is learning. Besides that, in the effort to reach the generation of democratic citizens in the modern era, high order thinking skills are also needed. This ability to think at a higher level requires someone to apply new information or prior knowledge. The purpose of this study is to describe the concepts of democratic skills in the HOTS stage in the modern era. The method in this study uses a descriptive qualitative approach. The concepts of democratic skills in the HOTS frame are civic skills, intellectual skills, and participation skills. Through this research, HOTS is expected to strengthen democratic skills in the modern era.
\end{abstract}

Keywords: Democratic skills; higher order thinking skills; modern paradigms.

\section{Introduction}

Indonesia adheres to a democratic government system, this has been stated in the 1945 Constitution (after the amendment) article 1 paragraph 1 reads "Sovereignty is in the hands of the people and implemented according to the Basic Law". This is also regulated in the constitution in article 1 paragraph (1) and paragraph (2), as well as in the temporary Constitution of 1950 in article 1 paragraph (1). As a diverse ethnic, linguistic, religious, cultural and social group, Indonesia has its own challenges. The main challenge of the Indonesian people is how to unite differences in a democratic society. A democratic society can be created if all people can know, trust and have a commitment to one another.

Democracy has become a central issue in the past decade related to the dynamics of social change and Indonesian state administration. People have high hopes for improvement as a result of the development of democracy in Indonesia, especially in the era of modernization. Indonesia, which is classified as a developing country in Southeast Asia, has resulted in many developments from the outside world who want to enter Indonesia or even force them to enter Indonesia. the modernization era which is marked by the rapid development of information and technology resulting in an increase in one's curiosity about various forms of information. This makes it seem as if the world without borders is the door to open windows, this term is known as globalization. Influences originating from the western world bring all negative and positive impacts. The rapid development among the people of Indonesia shows various developments. Starting from clothing fashion trends, lifestyles, and social order that changes with the emergence of a social gap in the social environment.

The Indonesian state continues to strive to achieve the ideals of the Indonesian nation as outlined in the opening of the 1945 Constitution. Various positive efforts continue to be made 
for the balance of the nation and towards the ideals of the Indonesian nation. The condition of people who are prone to misunderstandings receives so much information from the outside world. So many challenges that accompany the course of the development of the Indonesian state. Things that are prone to happen in the era of globalization in the community are people who are easily consumed by the news that is not yet certain. Globalization itself promises good and bad things in spreading information. The main trigger is in improving the technology that everyone can share news so easily. From one telecommunications tool to another telecommunications tool. This if left unchecked will result in disintegration that is capable of impacting social, cultural, religious and political aspects. Besides, it makes people who lack full trust in the government as a result of victims of hatred for the government whose uncertainty is not yet correct. For this reason, every community must be able to filter incoming information and news and find out the truth. This is as a form of balancing and neutralizing with the flow of information so swiftly behind the challenges of Indonesia's democratic conditions (Saputri and Prayogo, 2018: 263-264).

\section{Review of Literature}

\subsection{The Concept of Democracy in Indonesia}

The term democracy comes from the Greek, which is "demos" meaning people and "Kratos" means government. So democracy means popular government. Where people are included in the democracy and the people are also the holders of power and control the course of a government. Many of the scholars in the past who tried to describe what and how the meaning of democracy in a state administration. Aristotle argued that the notion of a rule of law arises from a policy that has a small state territory, such as cities and has a small population, unlike countries that currently have large areas and are heavily populated. In the policy, all state affairs are carried out by deliberation (ecclesia), where all citizens participate in the affairs of state administration (Irawan, 2007: 55). Democracy as a basis for state life in general, which gives an understanding that at the last level the people provide provisions in the main issues concerning their lives, including in assessing the policy of the state government because these policies determine people's lives (Rais, 1986: 5).

The State of Indonesia itself is a country that adheres to a democratic government system, this has been stated in the 1945 Constitution. The basis of Indonesia's democratic law is the 4th Precepts of Pancasila namely "populace led by Constitution of Indonesia", Opening of the 1945 Constitution -4, ".. Indonesian national independence was compiled in a constitution of the Indonesian state, which was formed in an arrangement of the Republic of Indonesia that was sovereign of the people ..", Article 1 paragraph (2) of the 1945 Constitution, "people's sovereignty is in the hands of the people and carried out in accordance with the constitution ", Article 2 paragraph (1) of the 1945 Constitution," The People's Consultative Assembly shall consist of members of the People's Representative Council and members of the Regional Representative Council who are elected through general elections and regulated further by law. Pancasila democracy which is just and expected to provide benefits to the wider community.

Indonesia in its efforts to democratize is inseparable from various challenges. The main challenge of the Indonesian nation is how to unite differences in a democratic society. A democratic society can be created if all people can know, trust and have a commitment to one another. The Indonesian state continues to strive to achieve the ideals of the Indonesian nation as outlined in the opening of the 1945 Constitution. Various positive efforts continue to be 
made for the balance of the nation and towards the ideals of the Indonesian nation, especially in the current era of modernization.

Indonesia has now walked the modernization era. Modernization in Indonesia is characterized by something fast, effective and efficient. Modern becomes an identity that seems to be attached to all devices of human life. The development of science and technology caused various changes in the political, social and cultural fields. But not all elements of society are aware of the logical consequences or impacts of the changes that occur. The era of modernization will continue to bring many changes that cannot be dammed. Therefore, the need for efforts to provide an understanding of all elements of society about the nature of the modernization era with all its logical consequences. Through providing a deeper and deeper understanding, the community will naturally be motivated to prepare to face and respond to these changes. This has become very important especially with efforts to encourage the national education sector.

\subsection{Democratic Skills}

Every country in the world has formalized its national education goals in the country's constitution so that it can deliver all its citizens out of colonialism, which is ignorance (ignorance) which has created spaces of poverty and oppression. Efforts to instill hope in citizens are well-formulated and planned in the country's national education goals. Indonesia's education system after the Reformation has experienced major changes in policy, especially in the development of the education sector, which is generally based on two new paradigms, namely autonomy and democratization. Law No. 32 of 2004 concerning Regional Autonomy has put the education sector as one that is autonomy with other regional development sectors based on regionalism. The autonomy of the education sector seeks to condition schools so that principals, teachers have a great responsibility in improving the quality of the learning process to improve the quality of learning outcomes.

Likewise, the objectives of Indonesia's national education have been formulated in such a way as to achieve the welfare of citizens. The purpose and function of education is formulated in the National Education System Law Number 20 Year 2003, namely that national education functions to develop capabilities and shape the dignified character and civilization of the nation in order to educate the life of the nation and aim to develop the potential of students to become human beings who believe and be devoted to God Almighty, noble, healthy, knowledgeable, capable, creative, independent, reaching citizens who are democratic, critical of the development of Science and Technology and responsible for themselves, the environment, the nation and state (Article 3) DEPDIKNAS, 2003).

Besides education also has the aim of humanizing humanity (humanization). The purpose of this education is very noble, Paulo Freire argues that education is free (Freire, 2007: 82-84). This noble educational goal must also be followed by a liberating educational process by packaging a fun educational process by creating various models and methods of learning.

Indonesia adheres to a democratic government system, this has been stated in the 1945 Constitution (after the amendment) article 1 paragraph 1 reads "Sovereignty is in the hands of the people and implemented according to the Basic Law". This is also regulated in the constitution in article 1 paragraph (1) and paragraph (2), as well as in the temporary Constitution of 1950 in article 1 paragraph (1). As a diverse ethnic, linguistic, religious, cultural and social group, Indonesia has its own challenges. The main challenge of the Indonesian 
people is how to unite differences in a democratic society. A democratic society can be created if all people can know, trust and have a commitment to one another.

Reaching a generation of citizens who have critical thinking skills and have democratic skills is one of the goals of national education. Citizens who have democratic skills are citizens who have a democratic attitude. Having critical thinking skills, or the ability to think skillfully can build a democratic individual. Sudarman said that someone who is not able to think openly will give rise to the potential that creates conflicts with other people. People who are not trained with good thinking skills, will position themselves as the owner of the best thinking, and consider others, owners of poor thinking skills. Someone who is not accustomed to the discussion, or debate, or dialogue, will consider himself the best owner of thought (Sudarman, 2013: 35).

Good critical thinking will meet intellectual standards, such as clarity, relevance, adequacy, coherence. Critical thinking also requires skills in thinking about assumptions, in asking questions about the concept of democracy that is being discussed before it becomes an option to be developed into a way of living together as a nation.

Critical thinking skills and democratic attitudes do not just emerge. Critical thinking skills and democratic attitudes are the results of an educational process. In many countries, the need for democratic education in schools to shape citizens' democratic attitudes is important and urgent as a solution to the problems of the modern world today. Democratic education has the aim of forming thinking skills, expressing thoughts freely, neatly, concisely and respecting the minds of others (Sanli \& Altun, 2015: 2-3).

The new paradigm of education demands that education be able to give birth to democratic people who will portray themselves as children of the nation in the process of community and state life. Reaching a generation of citizens who have critical thinking skills and democratic attitudes is one of the goals of national education. Democratic citizens are citizens who have a democratic attitude. Having critical thinking skills, or the ability to think skillfully can build a democratic individual.

Democratic education aims to prepare citizens to think critically and act democratically, through instilling activities in a new generation that is aware of three things. First, democracy is a form of community life that best guarantees the rights of citizens. Second, democracy is a learning process that cannot be simply copied from other communities. Third, the continuity of democracy depends on the success of transforming democratic values (freedom, equality and justice, and being loyal to a democratic political system (Sihono, 2011: 5).

The purpose of democratic education is to prepare citizens to think critically, and to behave democratically. The problem that arises: democratic education can be held in a bureaucratic, hierarchical-centralistic and elitist school environment, such as schools that exist today. Held and the success of democratic education requires reforms in the field of education related to academic freedom, diversity of education, and an overhaul of civics educational material (Sihono, 2011: 5).

Efforts to build a democratic culture, it needs to be understood that the formation of citizenship skills is highly prioritized so that students can understand the true meaning of democracy itself so that students can build the course of democracy correctly and become good citizens. One of the attitudes of good citizens is to have knowledge of democratic attitudes. As a good citizen or often called to be good citizenship, namely citizens who have intelligence both intellectually, emotionally, socially and spiritually, have a sense of pride and responsibility and can participate in community and state life to grow a sense of nationality and 
love for the motherland. Therefore good citizens need to be given the knowledge and experience of good citizens to have the skills to apply their democratic attitude in the school environment and the community.

Civic skills are skills developed from the knowledge of citizenship, this is so that the knowledge gained becomes meaningful because it can be used to deal with the problems of national and state life. Citizenship skills are developed based on citizenship knowledge. Citizenship skills are developed to provide the knowledge and skills needed to participate effectively in the community, participating experiences designed to strengthen the awareness and ability of students to excel and develop an understanding of the importance of active participation in citizenship.

According to Handoko (2007: 16) the fundamental implications of democratic culture, that the presence and presence of students as one component of the school will only be accepted, if the person concerned has the desire, is able, and is willing to make various types of adjustments in actions and behavior reflects acceptance of cultural democracy in accordance with the objectives of school programs.

Handoko (2007: 16) argues that democratic culture is intangible. Culture surrounds and influences what happens in the environment. Culture is a dynamic system concept, so it can be influenced by whatever happens in the learning process. Therefore there are several components in measuring students' democratic skills, including:

a. Civic Skills

Citizenship skills are an ability to apply citizenship knowledge that has been controlled by citizens. In a democratic society, citizens should be able to carry out their obligations and be responsible for all their actions, in addition to the rights that they obtain. Thus there is a balance between rights and obligations taking precedence over rights. Citizenship skills, in this case, include intellectual skills and the ability to actively participate in various problems of citizens.

"Life skills in this sense refer to the various abilities needed for a person to lead a successful, happy and dignified life in society. "Life skills are the abilities needed for life, ownership of complex thinking skills, effective communication skills. , the ability to build cooperation, carry out roles as responsible citizens, have readiness and skills to work, and have the character and ethics to enter the workforce".

Civic education generally refers to "... the kinds of courses work taking place within the context of the formalized schooling structure", and "problems of democracy". Civic education is treated as "... the foundational course work in a school designed to prepare ... young citizens for an active role in their communities in their adult lives" (Winataputra, 2007: 1). This means that civic education is a basic subject that is designed to prepare young citizens to be able to play an active role in society. The second essential component of civic education in a democratic society is civic skills. If citizens practice their rights and fulfill their responsibilities as sovereign members of society, they not only need to intellectual prowess, but they also need to have relevant intellectual and participatory skills.

b. Intellectual skills

The ability to think scientifically is the development of general thinking skills, but it leads to scientific activities that are more directed towards critical and creative thinking skills on various issues of citizenship. Branson (1999) describes several things in identifying intellectual skills, including: 
- Identifying: to recognize something that is still vague one must be able to distinguish it from others, classify it with something else that has similarities, and determine its origin.

- Describe: to describe objects, processes, institutions, functions, objectives, tools, and qualities that are clear or vague. To describes someone needs a written or verbal report about their characteristics.

- Explain: to identify, describe, clarify, or translate something, one can explain the causes of an event the meaning and importance of an event or idea.

- Evaluating a position: to use criteria or standards to make decisions about the strengths and weaknesses of the position of a particular issue, the objectives that the position puts forward, or the tools used to achieve that goal.

- Taking a position/position: to use criteria or standards to achieve a position a person can encourage choosing from various choices, or make new choices.

- Defending the position: to put forward arguments for the attitude taken and respond to arguments that are not agreed upon.

c. Participation skills

In addition to requiring intellectual knowledge and abilities, education for citizens in a democratic society must be focused on the skills needed to participate responsibly, effectively and scientifically, in the political process and civil society. These skills can be categorized as interactions (interacting), monitoring (monitoring), and influencing (influencing). Interaction deals with the skills of citizens in communicating and cooperating with others.

Branson (1998: 15-16) suggests several things to understand intellectual abilities, including:

- The ability to influence policies and decisions by collaborating with others.

- Describe clearly an important issue that makes it known by policymakers and decision-makers.

- Build coalitions, negotiate, compromise, and seek consensus.

- Manage conflict.

\section{Research Method}

This research uses descriptive research with a qualitative approach. According to Moleong (2014: 6), explaining that qualitative research aims to understand the phenomena about what is experienced by research subjects, for example behavior, perception, action, and others. Holistically with descriptions in the form of words and language, in a natural case context and utilizing various natural methods. Based on the type and approach used, this study aims to find out and describe the modern paradigm: democratic skills in the frame of high order thinking skills.

\section{Discussion}

Finding and implementing the concept of democracy is certainly the result of a critical thinking process. However, it cannot be concluded that students currently have critical thinking skills and good democratic attitudes as expected. This makes the responsibility of educators to 
be able to foster good democratic skills. Besides, educators also have a role as facilitators in developing thinking skills.

Wilson (2000) suggested that the ability to think is part of human intellectuals in cognitive processes. The ability to think is defined as cognitive skills that enable a person to understand information, apply knowledge, express complex concepts, criticize, revise according to the results of construction, solve problems, and make decisions.

Thinking is a mental activity that occurs when someone faces a problem or situation that must be solved. Thinking activities can be classified into lower-order thinking and higher-order thinking. According to Heong, et. al (2011) high-level thinking ability is defined as the widespread use of the mind to find new challenges. This ability to think at a higher level requires someone to apply new information or prior knowledge and manipulate information to reach possible answers in new situations. Woolfolk (2008) states that students who have highlevel thinking skills can distinguish between facts and opinions, identify relevant information, solve problems, and can infer the information that has been analyzed. Examples of abilities that are classified as this ability, namely: the ability to apply, analyze, synthesize, and evaluate (create).

Based on Bloom's taxonomy, higher-order thinking skills are thinking activities that involve a high-level cognitive hierarchy. In the taxonomic hierarchy Bloom consists of six levels, namely knowledge, comprehension, application, analysis, synthesis, and evaluation. Anderson \& Krathwohl (2001) developed Bloom's taxonomy into remembering, understanding, applying, analyzing, evaluating and creating. In its development remembering, understanding, applying are categorized in recalling and processing, while analyzing and evaluating are categorized in critical thinking and the last one creating is categorized in creative thinking. Thomas, Thorne \& Small (in Aprianti, 2013) conclude that higher-level thinking is a combination of critical thinking, creative thinking, and basic knowledge thinking.

High-level thinking in Bloom's taxonomy (2001 edition) begins with a cognitive process: analyzing, evaluating to creating something. At each level of the cognitive process students subject to metacognitive knowledge, ranging from strategic knowledge, knowledge about cognitive tasks, and knowledge about oneself. Analyzing is the process of breaking down material into parts and detecting how the parts are related to one another and related to the overall structure or purpose. The process of analyzing this involves differentiating, organizing, and attributing.

Evaluating is the process of making judgments based on certain criteria and standards. This process involves checking and critiquing. Creating is the process of combining elements to form a new whole and be logically connected or create an original product. This process involves generating, planning, and producing.

The six cognitive processes are hierarchical and interrelated. The higher the level of the thought process the higher the thinking skills needed. Thus to be able to analyze, evaluate and create well, students are required to be able to remember, understand and apply well in advance.

Resnick in Nur (2011) identifies the characteristics of higher-level thinking as follows: (1) higher-level thinking is non-algorithmic. That is, the sequence of actions cannot be fully determined in advance, (2) higher-order thinking tends to be complex. The overall sequence of steps cannot be "seen" only from one side of a particular view, (3) high-level thinking often produces multiple solutions, each solution has advantages and disadvantages, (4) high-level thinking involves careful consideration and interpretation, (5) higher-level thinking involves the application of multi-criteria so that sometimes criteria conflict with one another, (6) high- 
level thinking often involves uncertainty. Not all things related to the task being handled can be fully understood, (7) higher-level thinking involves self-regulation in the thought process. An individual cannot be seen as thinking higher-level if others who help at each stage, (8) thinking higher-level involves exploring meaning, and finding patterns in disorder, (9) thinking high-level is an effort as hard as possible and hard work.

High-level thinking involves the massive mental work required in elaboration and consideration. While Sudiarta (2006) explains the relationship of higher-level thinking with the following matters: (1) the ability to solve new problems that are non-routine and unexpected, (2) the ability to carry out activities of analysis, synthesis, systematic evaluation, (3) the ability to make various predictions that are useful for natural and life phenomena in an original, critical, and creative manner.

All thinking skills that have been described above can be developed through education and learning. Education and learning are seen as a vehicle that can develop students' thinking skills because both of them contained thinking activities. The concepts of education and learning, thinking activities are the core of all learning activities, and thinking activities will also emerge in the process of education and learning. During thinking activities take place, a person will involve all the feelings and desires for something that will be resolved. This thinking activity will facilitate and enhance one's ability to do, produce, or convey information. Besides addition, through the activity of thinking, students are also trained to be able to obtain, manage, analyze, synthesize, and utilize information to find solutions to a situation or problem.

Limbach \& Waugh (2010), identified five steps in the process of developing higher-order thinking skills that can be implemented in almost all learning environments of active students. The five steps are: (1) determining the formulation of learning that accelerates students to a higher level, (2) asking questions. The level of student thinking is directly proportional to the level of questions asked, (3) practice before assessment. Selecting learning activities that allow students to practice will encourage them to think critically, (4) review, refine, and improve learning, and (5) provide feedback and assessment of learning.

\section{Conclusion}

The ability to think of high-level thinking that has been described above should be owned by students as a provision in welcoming the global era, advances in information technology, the convergence of science and technology as a result of science, and the rise of creative industries in the future (Kemendikbud, 2013). Students who have good high-level thinking skills will commit to continue learning, growing, developing, and evolving. Addition students who can think at a higher level will be better able to interpret and review the information available and be able to use the information to solve the problem at hand.

Based on the above concept, the researcher views that education can not only be used as a vehicle or vehicle to improve the ability to think at a higher level, but also has the potential to change and shape the habits or thinking patterns of students. The ability to think at a high level, habits of thought and patterns of thinking is what later will foster democratic skills in the global era. 


\section{References}

Anderson, L.W., and Krathwohl, D.R. (2001). A Taxonomy for Learning, Teaching, and Assesing: A Revision of Bloom's Taxonomy of Educatioanl Objectives. New York: Addison Wesley Longman, Inc.

Aprianti, V. (2013). Pengaruh Penerapan Model Cooperative Learning Tipe Think Pair Share (TPS) Terhadap Kemampuan Berpikir KritisSiswa Pada Pembelajaran Ekonomi.UPI.repository.upi.edu.

Bambang, I., B. (2007). Perkembangan Demokrasi di Indonesia. Jurnal Hukum dan Dinamika Masyarakat, Vol. 5 No. 1, hlm 54-64.

Biesta, Gert J.J. (2011). Learning Democracy in School and Society. Rotterdam: Sense Publishers

Branson, M. S. (1999). Belajar “Civic Education” dari Amerika (Terjemahan Syarifudin dkk). Yogyakarta: LKIS.

Branson, M.S. (1998). The Role of Civic Education. Calabasas: CCE.

Depdiknas. (2003). Undang-Undang Nomor 20 Tahun 2003 tentang Sistem Pendidikan Nasional Jakarta.

Freire, P. (2007). Politik Pendidikan: Kebudayaan, Kekuasaan dan Pembebasan, terj: Agung Prihantoro. Yogyakarta : Pustaka Pelajar.

Handoko. (2007). Manajemen Personalia \& Sumber Daya Manusia. Jakarta: Rineka Cipta.

Heong, Y. M., Widad, J., Kiong, Tee Tze, Razali, M. (2011). The Level of Marzuno Higher Order Thinking Skills among Technical Education Students. International Journal of Social Science and Humanity, vol. 1, No.2.

Heong, Y. M., Widad, J., Kiong, Tee Tze, Razali, M. (2011). The Level of Marzuno Higher Order Thinking Skills among Technical Education Students. International Journal of Social Science and Humanity, vol. 1, No.2.

King, F. J., Goodson, L., Rohani, F. (2004). Higher Order Thinking Skill. A publication of the Educational Services Program, now known as the Center for Advancement of Learning and Assessment.

Limbach, B., and Waugh, W. (2010). Developing Higher Level Thinking. Journal of Instructional Pedagogies, vol. 3.

Moleong, J. L. (2014). Metodologi Penelitian Kualitatif (Edisi Revisi Cetakan ke-33). Bandung: Remaja Rosdakarya

Nur, M. (2011). Model Pembelajaran Berbasis Masalah. Surabaya: Universitas Negeri Surabaya.

Rais, A. (1986). Pengantar Dalam Demokrasi dan Proses Politik. Jakarta: LP3ES.

Richard A. E. (2011). Direct Democracy: Government of the People, by the People, and for the People. Harvard Journal of Law \& Public Policy. Vol. 34.

Robinson, D. (2005). Menjadi penerjemah profesional (Terjemahan). London and New York: Routledge.

Şanlı, Ö., and Altun, M. (2015). The significance of establishing democratic education environment at schools. Journal of Educational and Instructional Studies in The World. Vol. $5 . \quad$ No. $2 . \quad$ Retrieved from ttp://www.wjeis.org/FileUpload/ds217232/File/01.onder_sanli.pdf 
Saputri, W. D and Prayogo, B. E. (2018). Tantangan Demokrasi di Era Globalisasi Demi Mewujudkan Pencegahan Politik Uang dalam Pemilu. Seminar Nasional Hukum Universitas Negeri Semarang Volume 4 Nomor 2.

Sihono, T. (2011). Upaya Menuju Demokratisasi Pendidikan. Jurnal Ekonomi \& Pendidikan. Vol. 8. No. 1

Sudarman, M. (2013). Mengembangkan keterampilan berpikir kreatif. Jakarta: Rajawali Press.

Sudiarta, P. (2006). Pengembangan Model Pembelajaran Berorientasi Pemecahan Masalah Open-Ended Berbantuan LKM Untuk Meningkatkan Pemahaman Konsep Dan Hasil Belajar Mahasiswa Matakuliah Pengantar Dasar Matematika. Jurnal Pendidikan dan Pengajaran UNDIKSHA 39 Nomor 2.

Wilson, V. (2000). Educational forum on teaching thinking skills. Edinburgh: Scottish Executive Education Department.

Winataputra, U.S. and Budimansyah, D. (2007). Civic Education, Koteks, Landasan, Bahan Ajar dan Kultur Kelas. Bandung: UPI.

Woolfolk, A. (2008). Educational Psychology Active Learning Edition 10th ed. Pearson Education, Inc.

Zamroni. (2011). Pendidikan Demokrasi Pada Masyarakat Multikultural. Yogyakarta: Gavin Kalam Utama 